\title{
Role of Judges in Handling Criminal Procedures for Children through Diversion of Justice
}

\author{
Agra Sulchantifa Ulul Amri ${ }^{*}$ and Akhmad Khisni ${ }^{* *}$ \\ $\left.{ }^{*}\right)$ Master of Law, Faculty of Law, Universitas Islam Sultan Agung Semarang, E-mail: \\ agraululamri@gmail.com \\ ${ }^{* *}$ Faculty of Law, Universitas Islam Sultan Agung Semarang
}

\begin{abstract}
.
This study aims to answer the problem: What is the role of the judge in handling cases of juvenile crime through fair diversion? How can the handling of criminal acts through fair diversion have an impact in the future? The research method used is sociological juridical. This research yields the result that judges play a role in handling criminal cases through diversion because the parties can be brought together by the judge for settlement by deliberation, consensus without going through a judicial process, so that through the path of peace. Because diversion upholds the values of Pancasila, especially the 2nd and 5th principles, humanity, social justice and dignified justice can be realized, namely humanizing humans, the protection of children from stigma, labeling, mental and moral reform can be overcome. In addition, it is very necessary to carry out guidance and strict supervision of children in their daily interactions so that the child does not commit another criminal act. Keywords: Role of Judge; Child Crime; Diversion, Justice.
\end{abstract}

\section{Introduction}

The State of Indonesia is a constitutional state based on Pancasila as regulated in the 1945 Constitution of the Unitary State of the Republic of Indonesia, hereinafter abbreviated to the 1945 Constitution of the Republic of Indonesia known as the 1945 Constitution, particularly in Article 1 paragraph (3) which reads: "The State of Indonesia is a state based on law". This means that all aspects of life in this country are regulated based on the rule of law. In an effort to realize the enforcement of the rule of law in Indonesia, a legal product is needed, in this case a law, which functions as a regulator of all public actions as well as a means of coercion to society.The problem of children and their protection will never stop throughout the history of life, because children are the next generation of the nation and development, namely the generation that is prepared as the subject of implementing sustainable development and in control of a future of country, Indonesia is no exception.

Protection of Indonesian children means protecting the potential of human resources and developing the whole Indonesian people, towards a society that is fair and prosperous, spiritual material based on Pancasila and the 1945 Constitution. ${ }^{1}$ The Republic of Indonesia has ratified the convention on children's rights through Keppress No. 36 of 1990. This ratification is a state effort to provide protection for children. Of the various issues that exist in the Convention on the

\footnotetext{
${ }^{1}$ Nashriana. (2011). Perlindungan Hukum Pidana Bagi Anak di Indonesia, Jakarta: PT Raja Grafindo Persada. p. 1.
} 
Rights of the Child, one of which really needs special attention is children who need special protection, including children who are in conflict with the law. In the national law, special protection for criminal acts by children is also regulated in Act No. 11 of 2012 concerning the Juvenile Criminal Justice System and Act No. 35 of 2014 amendments to Act No. 23 of 2002 concerning Child Protection.

Act No. 11 of 2012 concerning the Juvenile Criminal Justice System, has provided special treatment to children who have committed a criminal act, both in procedural law and in the judiciary. This is because the nature of the child and their psychological condition in certain cases require special treatment as well as special protection, especially against actions which in essence can harm the mental and physical development of the child. This is realized by starting with special treatment at the time of detention, namely holding children apart from adults. In each level of examination, the child is obligedgiven legal assistance and accompanied by a social advisor or other companion in accordance with the provisions of laws and regulations.

On the way up to now what is mandated in Act No. 11 of 2012 concerning the Juvenile Criminal Justice System and Act No. 35 of 2014 amendments to Act No. 23 of 2002 concerning Child Protection is still constrained by the facilities and infrastructure provided by the Government, special prisons for children that only exist in certain cities, even the provincial capital such as Semarang City does not yet exist. This of course causes the fulfillment of children's rights as mandated by laws and conventions on children's rights. In addition, the lack of comprehensive socialization carried out by law enforcement officials including the police, prosecutors, and community organizations down to the lowest ranks has resulted in ineffective provision of legal protection for children.

Handling children in conflict with the law, Hakim always have to pay attention to the different conditions of children from adults. The basic nature of children as individuals who are still unstable, the future of the child as an asset of the nation, and the position of children in society that still need protection can be used as the basis for finding an alternative solution to prevent children from a formal criminal justice system, placing children in prison (penitentiary institutions) and stigmatization of the child's position as a prisoner. One solution that can be taken is in the handling of child criminal cases is the restorative justice approach, which is carried out by way of diversion. Diversion is the transfer of settlement of juvenile cases from criminal justice processes to processes outside of criminal justice.

Meanwhile, restorative justice is the process of resolving criminal cases by involving perpetrators, victims, families of perpetrators / victims, and other related parties to jointly seek a fair solution by emphasizing restoration to its original state, and not retaliation justice is considered as a way of thinking or a new paradigm in viewing a crime committed by a person. Therefore, judges at the Semarang District Court are required to be able to carry out diversion in handling cases of juvenile crime. The diversion of the juvenile justice process or what is known as diversion is useful to avoid the negative effects of further judicial processes in juvenile justice administration, for example labeling guilt convictions and sentencing. 
To what extent is the implementation of the juvenile criminal justice system carried out by the Semarang District Court Judges and the handling of whether it has prioritized diversion and prioritized justice as expected by the community in accordance with justice based on principle 2 (two) and principle 5 (five) of Pancasila? Based on the background of the aforementioned problems, the writer wants to study and analyze by discussing the problem of: "Role of Judges in Handling Criminal Procedures for Children through Diversion of Justice".

Based on the description above, this study aims to identify and analyze the role of judges in handling cases of juvenile crime through fair diversion, as well as handling crimes through fair diversion which can have an impact in the future.

\section{Research Methods}

The approach method used is sociological juridical. This research is qualitative. Research with a qualitative approach. Methods of data analysis using qualitative analysis methods Analytical activities consist of three activities that occur simultaneously, namely data reduction, data presentation, and drawing conclusions / verification.

\section{Result and Discussion}

\subsection{The Role of Judges in Handling Criminal Cases of Children through Just Diversion}

The role of judges in handling cases of child criminal acts through fair diversion, namely judges who examine casesChild punishment must be a judge who has interests and specifications (has a family and has children) in handling child criminal cases, of course through certification of child judges. The process of diversion in examinations at juvenile court, namely: the head of the court is obliged to appoint a judge or panel of judges to handle a juvenile case no later than 3 (three) days after receiving the case file from the public prosecutor. Then the judge is obliged to seek diversion no later than 7 (seven) days after being determined by the head of the district court as a judge. The diversion as intended shall be carried out for no later than 30 (thirty) days. During the diversion process, it can be carried out in the mediation room at the district court. In the case of the diversion process it was successful to reach an agreement. In the event that the diversion is not successful, the case will proceed to the trial stage. ${ }^{2}$

Decisions handed down to children can be in the form of crimes and actions. The form of punishment includes principal and additional penalties. The main crimes are: warning crimes; criminal with conditions (training outside institutions, community service, supervision); work training; coaching in institutions and prisons. Additional punishments consist of: confiscation of profits obtained from criminal acts; fulfillment of customary obligations. If in material law punishable by cumulative punishment in the form of imprisonment and a fine, then the penalty can be replaced with work training. Then the punishment imposed on children is prohibited from violating the dignity of the child.

${ }^{2}$ Interview with Sulistiyono, Judge of the Semarang District Court, on: November 6, 2020. 
Regarding penalties with conditions, the judge can imprisonment for a maximum of 2 (two) years. The terms referred to are 2 (two), namely general requirements (the child will not commit another criminal act while serving the criminal period with conditions), special conditions (to do or not to do certain things as stipulated in the judge's decision with due regard for the freedom of the child). The criminal period with special conditions is longer than the criminal period with general conditions. The period of the criminal period with a maximum requirement of 3 (three) years. During the criminal period with conditions, the public prosecutor shall supervise and guide the community to provide guidance so that the child meets the stipulated requirements, the status of the child as a social supervisor. While serving a conditional sentence,

If the judge decides that the child must be fostered outside the institution, the judge must determine which institution will foster the child. Supervision punishment that can be imposed on a child for a minimum of 3 (three) months and a maximum of 2 (two) years, and the child is placed under the supervision of a public prosecutor and guided by a social supervisor. The imprisonment imposed on a child is a maximum of $1 / 2$ (one half) of the maximum imprisonment for an adult. If the criminal offense committed by a child constitutes a criminal offense punishable by death or life imprisonment, the punishment imposed is a maximum imprisonment of 10 (ten) years.

Judges' decisions are in the form of actions, namely: return to parents / guardians; submission to the government; submission to someone; care in a mental hospital; care in an institution; the obligation to attend a formal education and / or training held by the government or private bodies; revocation of driving license; repairs resulting from criminal acts and reparation, which are then handed over to the parents or family under the supervision of a community supervisor. The analysis that the author can convey is that all thatthe Judge has tried to aim for justice, which sees the condition of the child and the child's future so that his / her behavior can be corrected and not repeat his criminal acts. In accordance with the Theory of Law Enforcement, the role of Investigators, Public Prosecutors and especially Judges has attempted to realize several ideas about justice and efforts have been made to allow deversion to exist for legal certainty, for the sake of upholding the law by applying applicable regulations, and returning it to people. old is a social benefit that must come true. The Pancasila Justice Theory, which is resolved through diversion, can restore the rights and fears of the victim if revenge arises, so that it will realize equality with the existence of peace.

As for the Islamic Penalty Theory, that with the role of the Judge having sought diversion through peace, it can prevent retaliation and will lead to improvement. Thus, based on efforts to reconcile and return children to their parents, it is the role of judges in handling cases of juvenile crime through fair diversion. Then after that the peace letter was asked for a ruling to the Chairman of the Semarang District Court and after that it was handed over to the social adviser to foster and monitor him, so that the child becomes good.

Community advisory officers have a very big role in efforts to diversify child cases. The role and duties of the social adviser are maximized since the beginning of case handling, even at the stage of being investigated by the police. The duties and roles of community supervisors regulated in the SPPA Law are to make 
community research reports for the sake of diversion, provide assistance, mentoring and supervision of children during the diversion process and implementation of the agreement, including reporting it to the court if diversion is not implemented, making community research reports for the benefit of Investigation, prosecution and trial in juvenile cases, both inside and outside the court, including in LPAS (Temporary Child Placement Institutions) and LPKA (Special Development Institutions for Children).

The social advisory officer report becomes considerations of law enforcers in seeking diversion, in addition to that, social advisers have a role in monitoring implementation diversion, whether it is implemented or not. Unfortunately, this regulation does not include sanctions for law enforcers who do not carry out diversion, so it is feared that law enforcers will not be obliged to accept recommendations from social advisers to diversify.Based on the description above, the authors can conclude and analyze that the diversion process can be carried out at each level of examination, namely starting at the level of investigation, prosecution level and examination level in juvenile court. Meanwhile, the social adviser has the task of making community research reports for diversion purposes. It has shown a truly fair handling because it is in accordance with the applicable legal regulations, namely Act No. 11 of 2012 concerning the Juvenile Criminal Justice System, which prioritizes diversion. This is in accordance with the justice of Pancasila, namely the 2nd and 5th principles of Pancasila, a just and fair humanity, is a civilized creature, namely: humans are essentially just and civilized, which means that humans must be fair to their God, thoroughly indiscriminate for all Indonesian people.

\subsection{Handling of Child Crime through Just Diversion Can Have an Impact in the Future}

The role of judges in providing a handling of child crimes through fair diversion can have an impact. In the future, it requires a more serious handling, considering that nationally and internationally, not only the number of crimes has increased but also the quality of the crimes. This requires efforts to prevent and overcome child criminal acts through the implementation of a juvenile criminal justice system. Reforming child criminal law in criminal policies is an integral part of efforts to protect and prosper the community.

This policy uses penal tools in Indonesia as embodied in Act No.11 of 2012 concerning the Juvenile Criminal Justice System, which is obliged to prioritize the restorative justice approach, namely diversion. Philosophically, this arrangement is in accordance with the Pancasila values contained in the second principle, fair and civilized humanity, and fifth, social justice for all Indonesian people. Meanwhile, juridically, this arrangement is a response to various national and international child protection instruments. This is expected to be able to avoid stigma and labeling during the judicial process to impose punishment on children, so that sustainable labeling, low self-esteem and guilt in children will not emerge. ${ }^{3}$

\footnotetext{
${ }^{3}$ Herlina, Apong. (2004). Perlindungan Terhadap Anak Yang Berhadapan Dengan Hukum Dengan Manual Pelatihan Untuk Polis. Jakarta: Polri dan Unicef. p.101.
} 
In an effort to avoid negative impacts during the juvenile justice process regulated in the United Nations Standard Minimum Rules For The Administration Of Juvenile Justice (The Beijing Rules), authorizes the authority of law enforcement officials to take discretionary actions in handling or resolving the problem of child violations without taking a formal path, including stopping or not continuing from the judicial process or returning and handing back to the community and other forms of social service activities. ${ }^{4}$ Although it has been recognized both nationally and internationally, diversion has not been implemented optimally. There are still several problems, such as: ${ }^{5}$ First, Children in conflict with the law are still undergoing the criminal justice process and are sentenced to a high number of imprisonment, it is recorded that in Central Java 89 children and National 1,739 children and Semarang 2 children were peace in cases of fights and the other was rehabilitated in a drug case. Second, the limited facilities and infrastructure in protecting children with legal conflicts, hereinafter referred to as AKH during the judicial process, both before and after the court decision and the minimal number of Child Special Development Institutions (LPKA) in each province, so that the LPKA and Lapas have not been completely separated.Adults and Child Detention Centers. Third, the real conditions in the field of diversion data have not been systematic, starting from the level of the Police, Bapas (Correctional Center). Ministry of Law and Human Rights, Ministry of Social Affairs, Ministry of Women and Children Empowerment, Ministry of Education and Ministry of Health) are still partial, sectoral in implementing their policies and authorities. ${ }^{6}$

The community feels that the criminal system that has been running so far has not been effective and has caused various problems. Imposition of imprisonment has not functioned optimally and has a deterrent effect. In addition, imprisonment damages the relationship of the convicted person to his family and society. ${ }^{7}$ This issue raises the idea of restorative justice as a substitute for justice for restitution and retribution that has been practiced in the criminal system.

Act No.11 of 2012 concerning the Juvenile Criminal Justice System defines restorative justice as the settlement of criminal cases by involving perpetrators, victims, families of perpetrators / victims, and other related parties to jointly seek a fair settlement by emphasizing restoration back to original state, and not retaliation. As a manifestation of the implementation of restorative justice in handling criminal cases, the term mediation in Criminal Cases or Mediation in Penal Matters (UK), Strabemiddeling (Netherlands), and Der Aubergerichliche is known.Tatausgleich (German). Mediation is a process of negotiating problem solving in which impartial outsiders work together with disputing parties to seek mutual agreement. The mediator is not authorized to decide disputes, but only assists the parties to resolve

\footnotetext{
${ }^{4}$ Nawawi, Barda. (1999). Beberapa Aspek Kebijakan Penegakan dan Pengembangan Hukum Pidana. Bandung: PT. Citra Aditya Bakti. p.165.

5 http://smslap.ditjenpas.go.id/public/arl/current/monthly/year/2020/month/1, accessed on December 1, 2020.

${ }^{6}$ Jurnal Syariah dan Hukum, de jure, Volume 7 Nomor 2, December 2015. p.179.

${ }^{7}$ A.Syukur, DS.Dewi and Fatahillah. (2011). Mediasi Penal: Penerapan Restorative Justice di Pengadilan Anak Indonesia. Depok: Indie Publishing. p.22.
} 
the issues that are delegated to him. ${ }^{8}$

Comparison of the Juvenile Criminal Justice System in the Netherlands, equipped with the kinder strafrecht with the Act of 5 July 1921 which took effect on 1 November 1922. Thus the Netherlands already has experience in juvenile justice. In the event that a person has reached the age of 16 but was not yet 18 years old at the time the offense was committed, in the case of confinement including substitute confinement, it is not applicable. The punishment for imprisonment for children (Juvenile detentoin) of less than 4 hours and not more than 14 days replaces the imprisonment sentence. Whereas the Juvenile Court is based on the principle of perent patrial, where the authorities must act if the child needs help and for children who commit crimes are not subject to criminal penalties, ${ }^{9}$

In Indonesia, the Juvenile Criminal Justice System, prioritizing diversion, stated Marliana, that diversion is a process of delegating children who are in conflict with the law from the criminal justice system to the informal system such as returning to social institutions, both the government and private. This action is done to avoid negative effects on the psyche and development of children. ${ }^{10}$ Diversion is an alternative to the Juvenile Criminal Justice System that is currently being implemented, although society must be based on the law, there must be flexibility to adapt to the complexities of legal problems faced today. Diversion can be carried out at the stage of investigation, prosecution and examination in court. The implementation of this diversion, on the one hand, protects children, where the community or victims are still protected. However, the main aim of implementing diversion is to avoid the negative effects of the criminal justice process, and it is replaced by guidance outside the criminal justice system by involving the wider community.

\section{Conclusion}

Whereas the role of judges in handling child criminal cases by pursuing diversion with peace, can prevent retaliation and will lead to improvement. Thus, based on efforts to reconcile and return children to their parents, it is the role of judges in handling cases of juvenile crime through fair diversion. Then after that the peace letter was asked for a ruling to the Chairman of the Semarang District Court, then submitted to the social adviser to foster and supervise him, so that the child becomes good and does not repeat the criminal act again.

Whereas in the future settlement of criminal cases through diversion must truly reflect dignified justice, namely humanizing humans so that no one is harmed, it must involve children, victims, parents, social officers and the community. Then it mustdelegating children who are in conflict with the law from the criminal justice system to the informal system such as returning to social institutions, both the government and private. This action is done to avoid negative effects on the psyche and development of children.

\footnotetext{
8 Umam, Khotibul. (2010). Penyelesaian Sengketa di Luar Pengadilan, Yogyakarta: Pustaka Yustisia. p.10.

${ }^{9}$ http://broms-gregorius.blogspot.com accessed on: November 30, 2020.

10 Marliana. (2012), Peradilan Pidana Anak di Indonesia Pengembangan Konsep Diversi dan Restoratif Justice, Bandung: Refika Aditama. p.19.
} 


\section{References}

\section{Journal:}

[1] Jurnal Syariah dan Hukum, de jure, Volume 7 Nomor 2, December 2015.

\section{Books:}

[1] Herlina, Apong. (2004). Perlindungan Terhadap Anak Yang Berhadapan Dengan Hukum Dengan Manual Pelatihan Untuk Polisi. Jakarta: Polri dan Unicef.

[2] Nawawi, Barda. (1999). Beberapa Aspek Kebijakan Penegakan dan Pengembangan Hukum Pidana. Bandung: PT. Citra Aditya Bakti.

[3] A.Syukur, DS.Dewi and Fatahillah. (2011). Mediasi Penal: Penerapan Restorative Justice di Pengadilan Anak Indonesia. Depok: Indie Publishing.

[4] Umam, Khotibul. (2010). Penyelesaian Sengketa di Luar Pengadilan, Yogyakarta: Pustaka Yustisia.

[5] Marliana. (2012), Peradilan Pidana Anak di Indonesia Pengembangan Konsep Diversi dan Restoratif Justice, Bandung: Refika Aditama.

[6] Nashriana. (2011). Perlindungan Hukum Pidana Bagi Anak di Indonesia, Jakarta: PT Raja Grafindo Persada.

\section{Internet:}

[1] http://smslap.ditjenpas.go.id/public/arl/current/monthly/year/2020/mont $\underline{\mathrm{h} / 1}$, accessed on December 1, 2020.

[2] http://broms-gregorius.blogspot.com accessed on: November 30, 2020. 